\title{
Death Penalty in China after the Ninth Amendment: Legislatively Abolishing and Judicially Limiting
}

\author{
Huang $\mathrm{G}^{*}$ \\ Faculty of Law, University of Debrecen, Hungary
}

*Corresponding author: Huang G, Faculty of Law, University of Debrecen, Hungary, Email: huanggui598@ gmail.com, hg_0125@126.com

Citation: Huang G (2016) Death Penalty in China after the Ninth Amendment: Legislatively Abolishing and Judicially Limiting. J Forensic Sci Criminol 4(3): 303. doi: 10.15744/2348-9804.4.303

Received Date: March 18, 2016 Accepted Date: June 29, 2016 Published Date: June 30, 2016

\begin{abstract}
This paper supplies some possible approaches to death penalty reform in China based on analyzing the reforms attempted by the Ninth Amendment. There now are 46 crimes punishable by death, and this penalty still plays a significant role in the criminal punishment structure. In order to abolish entirely the death penalty in Penal Code, the legislature of China should gradually abolish the death penalty for non-violent crimes and then for non-lethal violent crimes and finally for lethal violent crimes. In the case where the death penalty hasn't yet been abolished completely, increasing the applicable conditions of suspension of execution of death penalty and reducing the scope of applicable objects (elderly defendants and other kinds of special objects) of the death penalty would be an effective road to controlling and limiting the use of the death penalty in judicial practice.
\end{abstract}

Keywords: Death Penalty; The Eighth Amendment; The Ninth Amendment; Suspension of Execution of death; Immediate Execution of Death; China

\section{Introduction}

“The death penalty is like no other punishment. It is ultimate, most consequential and totally irreversible penalty", which thus causes it to always be on the list of the hottest topics among Chinese criminal law circles and even in the social public discourse [1]. Likewise, it has also become a significant focus of global society in terms of the construction of rule of law and the development of human rights in China. The reform of the death penalty system has already become the most significant area of criminal punishment reform in China in recent years.

Three significant attempts at reforming the death penalty system have already taken place in recent years, namely, the power to review the death sentences was withdrawn by the Supreme People's Court of P.R.C (Hereinafter, SPC) from the local High Courts in every province and Military Courts since January $1^{\text {st }}, 2007$, so that the SPC can uniformly exercise the power of reviewing and further improve the standards and conditions of evidence and procedure in death penalty sentencing. This is the first step. And the second one is the Eighth Amendment to Criminal Law of P.R.C. (hereafter, the Eighth Amendment) which was adopted on February $25^{\text {th }}, 2011$, and abolished the death penalty for 13 economic and nonviolent crimes, reducing the number of crimes punishable by death from 68 to 55, and banned capital punishment for offenders over the age of 75. It started a process of gradually abolishing the death penalty in China. Professor Carolyn Hoyle in the UK pointed out that "important in themselves, these reforms are emblematic of China's emerging commitment to limit the scope and practice of capital punishment in stages, with, as it state to the UN Human Rights Council in 2007, the final aim of abolition [2]." And another further step of death penalty reform is that the Ninth Amendment to Criminal Law of P.R.C (Hereinafter, the Ninth Amendment) was adopted on August 29 ${ }^{\text {th }}, 2015$, which also abolished death penalty for 9 crimes and reformed the relevant death penalty system.

Now, these reforms have already been underway and it may be said that the Chinese government has "already made remarkable achievements in the legislative and judicial reforms of death penalty [3]." In other words, these reforms theoretically highlight not only the changes of the Chinese traditional concepts of criminal legislation, particularly in the outlooks of and attitude of the death penalty system, but also judicially remove the barrier from death penalty system for the international assistance in criminal matters. The Vice-Chairmen of Law Committee of the National People's Congress of P.R.C., Li Shishi, when he introduced the Explanations for the Draft of the Ninth Amendment to Criminal Law of P.R.C. said that "since the death penalty for 13 economic and non-violent crimes was abolished by the Eighth Amendment in 2011, the general security situation of China society is within a controllable range and the number of serious crimes is stable with a slight decline. The practice has already suggested that abolishing 
the death penalty for 13 crimes by the Eighth Amendment didn't bring any negative impact on the society, and sections of the society in China have positively reacted to and commented on the death penalty abolition [4]." The reform of the death penalty, therefore, doesn't have an evidently negative impact upon the society, much less does it have a negative impact upon society's peace and security.

The Ninth Amendment, which was adopted on August $29^{\text {th }}$, and came into force on November $1^{\text {st }}, 2015$, has significantly modified the present Penal Code, especially the death penalty system. It has pushed the death penalty reform further. All these reforms include the following: 1) it has further reduced the amount of crimes punishable by death stipulated by specific provisions of Penal Code; 2 ) it has further improved the executive conditions of which the suspension was revoked and imposed immediate execution, which is a reform of great significance for China's present death penalty system. This paper, thus, would like to explore, based on the now available relevant research, the legislative potential approaches to death penalty reform after the Ninth Amendment. These approaches should mainly include reducing the number of crimes punishable by death stipulated by the Penal Code, exploring the reform of the death penalty with suspension of the execution system, improving the applicable conditions of death penalty and limiting the scope of applicable objects of death penalty.

\section{The strategy of reducing the number of crimes punishable by death}

Reducing the number of crimes punishable by death is a key approach to reforming the death penalty system, because it is the only way that the death penalty can be entirely abolished in China. Based on the Eighth Amendment, the Ninth Amendment reduces further the number of crimes punishable by death stipulated by the specific provisions of the Penal Code. This part will explore the strategy of abolishing entirely the death penalty by reducing the number of crimes punishable by death on the basis of analyzing the relevant important points of the death penalty for certain crimes abolished by the Ninth Amendment.

\section{The death punishment abolished by the Ninth Amendment}

Considering the requirements of domestic national policies, the public security situation and society economic, the Penal Code adopted in 1997 stipulated 68 crimes punishable by death and the relevant application restrictions. During the process of modifying the 1997 Penal Code, the legislature and criminal scholars have realized the number of crimes punishable by death are too many, and it went against the international trend of abolition, but, considering the society of that day was still experiencing a regime transition, and the relatively severe public security situation and the requirement of criminal policy to severely cracking down on crime, the Penal Code did not abolish the death penalty until the Eighth Amendment. As Eric Neumayer pointed out, "where violent crime and homicide rates are very high, the perceived threat might be more likely to be answered by the ultimate punishment [2]. After a long period of theoretically and practically discussing and exploring the reform of the death penalty in China, reducing the number of crimes punishable by death was the first important step and the other reforms of the death penalty were substantially conducted from the aspect of legislation, so as to promote human rights protection and criminal judicial reform.

The Ninth Amendment further reduced the number of crimes punishable by death from 55 to 46, namely, the death penalty for crimes of smuggling weapons, ammunition, crimes of smuggling nuclear materials, crimes of smuggling counterfeit currency, crimes of counterfeiting currency, crimes of raising funds by means of fraud, crimes of organizing prostitution, crimes of forcing another person to engage in prostitution, crimes of obstructing a commander or a person on duty from performing his duty, and crimes of fabricating rumors to mislead others during wartime. Thus, China has taken another solid step towards the final goal of complete de facto and de jure abolishment of the death penalty by reducing the number of crimes punishable by death.

All the 9 crimes punishable by death which were abolished by the Ninth Amendment have the following characteristics: 1) The majority of them are economic and non-violent crimes, while a few of them are non-lethal acts of interpersonal violence. Amongst these crimes, 5 of them relate to disrupting the order of the socialist market economy, 2 of them are crimes of obstructing the administration of public order, of which the crime of forcing another person into engaging in prostitution normally is conducted by means of violence, and 2 of them are crimes of servicemen's transgression of duties, of which the crime of obstructing a commander or a person on duty from performing his duty is conducted normally by the means of violence. At the same time, the death penalty for the crimes of smuggling weapons and ammunition, crimes of smuggling nuclear materials and crimes of smuggling counterfeit currency, which are stipulated by the Article 151, is also abolishing indirectly "it will result in the death penalty for crimes of shielding smuggling with arms, which is stipulated by the Article 157(1), is also abolished [3]." Because Article 157 (1) stipulates that "whoever shields smuggling with arms shall be given a heavier punishment in accordance with the provisions in the first or fourth paragraph of Article 151 of this law", and the death penalty stipulated by Article 151 has already been abolished [5]. 2) The death penalty for 9 crimes abolished by the Ninth Amendment "is seldom applied in judicial practice, and if abolished, they would not bring any negative impact on the social public security [6]." During the discussion of the draft of the Ninth Amendment, some scholars and judges pointed out that "the death penalty in cases of the 9 crimes is to be abolished and is scarcely or very rarely applied in judicial practice [7]." For example, in cases of the death penalty for the crimes of smuggling unclear materials, crimes of obstructing a commander or a person on duty from performing his duty and crimes of fabricating rumors to mislead others during wartime are three crimes that are never announced in judicial practice because there never has been such a case up until the present time, and the death penalty for the crimes of smuggling weapons and ammunition, and crimes 
of smuggling counterfeit currency are scarcely applied. For the death penalty for the crimes of raising funds by means of fraud, in recent years these kinds of cases' punishment are always of great concern to the broader society, particularly in the case of Wu Ying, who in the first and second trial was sentenced to death. Most people, including most criminal law scholars, were opposed to this death sentence. Finally, the SPC commuted the death sentence to life-imprisonment. In addition, the crimes of organizing prostitution and forcing another person to engage in prostitution happen frequently, and 'Tang Hui's daughter case was the most representative of this category in the last several years, which caused the whole society to discuss and be concerned with the issue of the death penalty for the crime of forcing another person to engage in prostitution. In this case, the defendant was sentenced to death due to having organized and forced Tang Hui's daughter, who was around 13 years old, to engage in prostitution. And finally, the SPC commuted the death sentence to life-imprisonment. 3) Reducing the number of crimes punishable by death in a great range and scope. The death penalty for 13 crimes was abolished by the Eighth Amendment, which makes up $19.1 \%$ of all the number of crimes punishable by death; the Ninth Amendment abolished 9 crimes punishable by death, which made up $16.4 \%$ of crimes eligible for punishment by the death penalty. These two occasions when the number of crimes punishable by death were reduced, were evidently of a great range and percentage.

After the vote approving the draft of the Ninth Amendment, the Chairman of the Standing Committee of the National People's Congress (NPC), Zhang Dejiang, stated that the Ninth Amendment implements the spirit of the $3^{\text {rd }}$ and $4^{\text {th }}$ Session of the $18^{\text {th }}$ National Congress of the Communist Party of China (CPC), and carries out the requirements and assignments of furthering the reform of the judicial system, and it significantly improves, supplements and amends the Penal Code in accordance with the criminal policy of combining punishment with leniency and judicial practice [8]. The Ninth Amendment has further promoted the reform of the death penalty and human rights protection. Admittedly, the Ninth Amendment marks just a small step towards complete abolition, however, it still requires many more steps and measures. In other words, death penalty reform is still under way, and it still needs to reduce legislatively the number of crimes punishable by death until the complete de jure abolishment of the death penalty takes place. However, the Chinese legislature has to face the issue as to what kinds of approaches and strategies should be adopted in order to complete the abolition. And it is also a problem that the legislature has to consider and criminal scholars have to research after the adopting the Ninth Amendment. Therefore, the next part of this paper will try to elaborate upon my opinions about the approaches and strategies of the reform of the death penalty.

\section{The strategy of reducing the number of crimes punishable by death}

The Eighth and Ninth Amendment have dramatically reduced the number of crimes punishable by death stipulated by the specific provisions; there are still 46 crimes punishable by death. And the Chinese legislature has to reduce entirely this number of crimes step by step in the future. The approaches and strategies below should be adopted for the next steps.

Strategy one: abolishing the death penalty for non-violent crimes: The Eighth and Ninth Amendment have abolished the death penalty for 13 economic and non-violent crimes and 9 crimes respectively. This kind of trend and style of reducing the number of crimes punishable by death will be the significant and appropriate approach and strategy for reform of the death penalty in China, and it is basic on the distributed situation of crime punishable by death in the specific provisions of Penal Code and judicial practice. The Table 1 below shows the distributed situations of crimes punishable by death.

\begin{tabular}{|c|c|c|c|c|c|c|c|c|}
\hline Crimes & $\begin{array}{c}\text { Crimes of } \\
\text { endan- } \\
\text { gering } \\
\text { natioinal } \\
\text { security }\end{array}$ & $\begin{array}{c}\text { Crimes of } \\
\text { endanger- } \\
\text { ing public } \\
\text { secutiry }\end{array}$ & $\begin{array}{c}\text { Crimes of } \\
\text { disrupting } \\
\text { the order of } \\
\text { the socialist } \\
\text { market } \\
\text { economy }\end{array}$ & $\begin{array}{c}\text { Crimes of } \\
\text { infringing } \\
\text { upon citizens's } \\
\text { right of } \\
\text { person and } \\
\text { democratice } \\
\text { rights }\end{array}$ & $\begin{array}{c}\text { Crimes of } \\
\text { property } \\
\text { violation }\end{array}$ & $\begin{array}{c}\text { Crimes } \\
\text { obstruct- } \\
\text { ing the } \\
\text { admin- } \\
\text { istration } \\
\text { of public } \\
\text { order }\end{array}$ & $\begin{array}{c}\text { Crimes of } \\
\text { impairing } \\
\text { the interests } \\
\text { of national } \\
\text { defence }\end{array}$ \\
$\begin{array}{c}\text { The number } \\
\text { of crimes } \\
\text { punishable by } \\
\text { death }\end{array}$
\end{tabular}

Table 1: The distributed situations of crimes punishable by death

The table shows that there are 46 crimes punishable by death in the present Penal Code, of which there are 24 crimes of a nonviolent nature, occupying 52.2\%. Even after two reductions by the Eighth and Ninth Amendment, the percentage of non-violent crimes punishable by death is still large, which thus determines that the focus of death penalty reform in China in the future should be on the abolition of the death penalty for non-violent crimes.

At the same time, in the judicial practice of China, the actual applicable rate of non-violent crimes also determine that the focus of death penalty reform in China in the future should be on abolishing the death penalty for non-violent crimes. Since the present 
Penal Code was enacted in 1997, the death penalty for the crimes of impairing the interests of national defence, crimes of servicemen's transgression of duties and most crimes of endangering national security have never been applied up until the present time, and it seems that this form of punishment in these cases has been put aside. The death penalty used to be frequently applied in the past for the crimes of embezzlement and bribery, but this has not been the judicial practice in recent years, including the implementation of the death penalty with immediate execution. Therefore, in accordance with the judicial practice in China, abolishing the death penalty for non-violent crimes would not have any practical negative impact.

Furthermore, non-violent crime is very substantially different from violent crime, due to the latter's infringements upon the right to life and right to health, and the former does not directly endanger another person's right to life. So, sentencing the criminal who committed extremely serious non-violent crimes to death is in fact out of keeping with the essential balance between crime and punishment. "Non-violent crime does not only doesn't include the violent factor in terms of constitutive elements of a crime, but also doesn't take another person's life as the target of crime. So the nature of social harmfulness of this kind of crime is absolutely different from such homicide as violent crime, and they could not view as the serious crime. But in accordance with the present Penalty Code, the maximum punishment prescribed is the death penalty for these two kinds of crimes, which is doubtlessly against the principle of suitable punishment for crime [9]." Non-violent crimes will become the preference for China to reform the death penalty system.

Strategy two: reducing the number of non-lethal violent crime punishable by death: Non-lethal violent crime refers to those crimes committed by violent means but which don't cause the victim's death. For example, the crime of forcing other person to engage in prostitution and the crime of obstructing a commander or a person on duty from performing his duties are non-lethal violent crime. The Ninth Amendment abolished the death penalty for economic and non-lethal violent crimes, going beyond the limitations of the Eighth Amendment which only abolished the death penalty for economic and non-violent crime. "It (the Ninth Amendment) has now taken a step to abolish the death penalty for non-lethal violent crime precedent, and in the future, China should keep on moving toward abolishing the death penalty for this kind of crime [3]."

After enactment of the Ninth Amendment, in the present Penal Code there are still 22 violent crimes punishable by death, most of which are stipulated by Chapter II (10 Crimes of endangering public security) and Chapter IV (4 crimes of infringing upon citizens' right of the person) in The Specific Provisions of Penal Code. The non-lethal violent crimes mainly include crimes of stealing or forcibly seizing any guns, ammunition or explosives, or stealing or forcibly seizing poisonous or radioactive substances, infectious disease pathogens (Article 127), crime of rape (Article 236), crime of abducting and trafficking in women or children (Article 240), crime of robbery (Article 263), crime of smuggling, trafficking in, transporting and manufacturing narcotic drugs (Article 347), and so on. According to traditional Chinese thinking, the harmful social consequences caused by these crimes are very serious and the perpetrators should be sentenced to death for committing them. And for these kinds of crimes, now, "China remains heavily dependent on the death penalty to control them [10]." To a great extent, China is still very resistant to abolishing the death penalty for these kinds of crimes. Non-lethal violent crimes, normally, are committed by violent means and cause a serious harmful social consequence, and the culpability of the perpetrator who commits this kind of crime is much more than that of the perpetrator who commits a non-violent crime. As for the value of life, the direct result of the death penalty is far more than the result caused by the non-lethal violent crime. Therefore, stipulating the death penalty for the non-lethal violent crime, to a great extent, implies that it is unsuitable punishment for the crime. So, China should abolish the death penalty for non-lethal violent crime. Abolishing the death penalty for non-lethal violent crime lays the groundwork for further abolishing the death penalty for lethal violent crime.

Strategy three: strictly limiting the application of death penalty for lethal violent crime until entirely abolishing the death penalty: Lethal violent crime refers to the crime of infringing or illegally depriving another person of their right to life by means of violence, such as the crime of hijacking aircraft (Article 121), and the crime of homicide (Article 232). All these kinds of crimes are punishable by death in light of the Penal Code. The nature of the death penalty for this kind of crime is called "absolutely determinate death penalty" or called mandatory death penalty [11]. And all this time, "the death penalty is mainly applied to such homicide, crime of intentional injury as only a few types of serious crimes [3]." Abolishing the death penalty for lethal violent crime would be the last strategy of death penalty system reform in China and it will be the most difficult. On the one hand, lethal violent crime has the most serious reverse-ethic, and it also easily raises the whole society concerns and easily sparks outrage. This can be clearly seen in recent cases, such as that of Li Changkui, who raped and killed his fiancée and then killed the fiancée's brother, and the case of Yao Jiaxin, who cruelly killed a woman [12,13]. These two cases called the public's attention to lethal violent crime and the death penalty system, and caused the society to intensively debate whether these two perpetrators shall be sentenced to death or not. Finally, however, the opponents of the death penalty really lost to the proponent. And this result was reflected in the final judgments of these two cases. On the other hand, the death penalty for lethal violent crime is in line with traditional Chinese concepts of retribution, which include 'death to the killer, prison to the violence. "This traditional concept has already survived more than one thousand years in China, and until now the revenge consciousness and retribution concept remain ingrained in Chinese thinking, and the psychological expectation of retribution can distinctly be found amongst the Chinese [14]." The traditional concept of "life for a life" has a firm foundation in the whole society and it has a deep influence on the criminal legislation and also provides a strong basis for sentencing the criminal who committed lethal violent crime to death. In addition, 
"immediately abolishing entirely the death penalty de jure and de facto would be too sudden to be accepted by the current social reality in China, because social support for complete abolition is lacking. But it doesn't mean that the public security now is in a bad situation; it was deeply impacted by the large population, the model of criminal legislation and the model of social control instead [15]." The complete abolition of the death penalty for lethal violent crime is at this stage unrealistic, but it should be limited by legislation. One important step is to amend the provisions of mandatory death penalty in the Penal Code. There are 4 crimes punishable by mandatory death penalty in the present Penal Code, namely, the crime of hijacking aircraft (Article 121), crime of kidnapping (Article 239), crime of abducting and trafficking in a woman or child (Article 240) and crime of instigating a riot to escape from prison or gather people to raid a prison with weapons. In accordance with these provisions, "if the crime falls under any category provided by the Penal Code, the defender shall be sentenced to death, except if he or she due to the circumstances of a crime calls for a lighter or mitigated punishment or exemption from punishment under the provisions of Penal Code, or he or she is in the situation that the death penalty shall not be imposed on him or her [11]." To a great extent, therefore, the judicial discretion of the judge in the process of sentencing is limited. As for the policy of 'strictly controlling and applying the death penalty deliberately', the terms of mandatory death penalty is nothing else but will only bring the possibility that the death policy will be ignored by the judge. This kind of provision, thus, should be amended and replaced by life-imprisonment for the sake of strictly controlling and limiting the death penalty for lethal violent crime.

\section{The strategy of reforming the system of death penalty with suspension of execution \\ The death penalty with suspension of execution and its reforms conducted by the Ninth Amendment}

The death penalty with the suspension of execution is a systematic characteristic of China, which "can be traced back to the period of the Great Revolution. Decision on the Ways to Punish Imperialism in Su Area in November, 1930, provided that the death penalty with the suspension of execution could be imposed on the foreign criminal" [16]. Article 48(1) of the Penal Code provides that "the death penalty shall only be applied to criminals who have committed extremely serious crimes. If the immediate execution of a criminal punishable by death is not deemed necessary, a two-year suspension of execution may be pronounced simultaneously with the imposition of the death sentence [17]." Based on this provision, one of the functions of death penalty with suspension of execution is limiting the execution of the death penalty. And this function can also be embodied in the previous Article 50(1) which states that "anyone who is sentenced to death with a suspension of execution and commits no intentional crime during the period of suspension, his punishment shall be commuted to life imprisonment upon the expiration of the two-year period; if he has truly performed major meritorious service, his punishment shall be commuted to a fixed-term imprisonment of no less than 15 years but not more than 20 years upon the expiration of the two-year period; if it is verified that he has committed an intentional crime, the death penalty shall be executed upon verification and approval of the Supreme People's Court [18]."

The system of death penalty with suspension of execution has already been amended by the Ninth Amendment for the sake of improving its function of limiting the execution of the death penalty. In accordance with Article 2 of the Ninth Amendment, the previous Article 50(1), which stated that "if it is verified that he has committed an intentional crime, the death penalty shall be executed upon verification and approval of the Supreme People's Court" is amended by the Ninth to "if he has committed an intentional crime, and of which circumstances are flagrant, the death penalty shall be executed upon verification and approval of the Supreme People's Court; if he has committed an intentional crime but the death penalty is not executed, the terms of suspension of execution of a death penalty shall be recounted again, and reported to the Supreme People's Court for the record" [19]. So the system of the death penalty with suspension of execution was reformed from two aspects, namely, firstly, "it raises further the thresholds of the suspension of execution of a death penalty commuted to immediate execution [20].", i.e. the previous terms of "it is verified" is amended to "circumstances are flagrant"; secondly, it increases the probation period of suspension of execution, in other words, it looks like putting the criminal onto a longer "death row" again [21]. The Ninth Amendment provides that if he or she has committed an intentional crime during the probation period of the suspension of execution and the circumstances are not fragrant, the death penalty shall not be executed, but the terms of the suspension of execution of a death penalty shall be recounted again.

As for the reform of the death penalty with the suspension of execution, some scholars have asserted that "the death penalty with suspension of execution should serve as a necessary procedure of the execution of death penalty", and they also think that it is the necessary preparation for abolishing entirely death penalty, and it can play an important role in limiting the application of immediate execution of death penalty overall under the premise of the death penalty system being retained in the Penal Code, and it also meets the requirement of the present conditions of China [22]. Some other scholars hold that the applicable conditions of the death penalty with suspension of execution are vague and the relevant provisions lack of standardization and legal positivism, and so it isn't consistent with the formality, which is about the explicit requirement of legislative language, of the principle of legality and its substance, which requires constructing a secure and stable social order, which is expected by the citizens. In addition, there is not a clear distinguishable applicable standard between suspension of execution and immediate execution of a death penalty [23]. In the case where the death penalty can't be entirely abolished both de facto and de jure in China, amending and improving the system of death penalty with suspension of execution will surely be a significant strategy for strictly controlling and limiting the use of death penalty in judicial practice. This paper insists that the present system of the death penalty with 
suspension of execution could be improved through increasing the applicable conditions of the suspension of execution of a death penalty commuted to immediate execution and further clearing the basic condition between suspension of execution and immediate execution of a death penalty.

\section{Further increasing the applicable conditions of the suspension of execution commuted to immediate execution}

The previous Article 50 of the Penal Code was amended by the Ninth Amendment to "if he has committed an intentional crime, and of which circumstances are flagrant, the death penalty shall be executed upon verification and approval of the Supreme People's Court" [19]. From this amendment, the most significant change is that the terms of "it is verified" was replaced by "of which circumstances are flagrant", and so making the suspension of execution of a death penalty only can be commuted to immediately execution upon the inmate has committed intention crime and the circumstances of this crime are flagrant. In other words, the conditions of suspension of execution of a death penalty commuted to immediate execution are significantly increased. However, until now China's relevant judicial authorities haven't enacted judicial interpretation for the Ninth Amendment, so that the meaning of the terms of 'the circumstances of this crime are flagrant' is not clear, namely, what is the 'circumstances are flagrant'? It is still a controversial issue. Generally, the 'circumstances are flagrant can be determined based on the concrete crime in accordance with the Penal Code and its relevant judicial interpretations. However, the circumstances in different crimes are different, and so the definition and scope of 'the circumstances are flagrant' are totally different and wide, and it affords a broad discretion to the judge, and finally it will result in a consequence that of the judgments about death sentencing are of great disparity. The terms of 'the circumstances are flagrant' here aren't scientific and rational. For this, before the Ninth Amendment was adopted, a famous Chinese scholar, Prof. Zhao Bingzhi, pointed out that "the expression of 'the circumstances are flagrant' is too abstract and vague to limit its function of limiting the suspension of execution commuted to immediate execution." And he further argued that "in order to further limit the revoking of suspension of execution, the threshold of commute needed to be increased by the Ninth Amendment or future other amendments to 'if he has committed crime and is sentenced to no less than 5 years imprisonment [3]." This paper agrees with this suggestion. However, his suggestion was not accepted by China's legislator.

The terms of 'the circumstances are flagrant' can be found in 10 clauses in the specific provisions of the present Penal Code, which are Article 133(2) (crime of dangerous driving), Article 236(3) (crime of rape), Article 250(crime of publishing a discriminating or humiliating minority work), Article 255 (crime of retaliating against accountants or statisticians), Article 260 (crime of maltreating), Article 260a (crime of maltreating the person under guardianship or nursing), Article 261 (crime of abandonment), Article 293 (crime of provocation), Article 443 (crime of maltreating subordinate), Article 444 (crime of abandoning a wounded or sick serviceman), and Article 448 (crime of maltreating a prisoner of war). In the judicial interpretations for these provisions (crimes), 'the circumstances are flagrant' is differently interpreted according to each concrete crime's harmful consequences and actual results, and the corresponding punishment also varies, of which the minimum statutory sentence is public surveillance, such as the penalty for 'the circumstances are flagrant' in the Article 250, Article 260, Article 260a, Article 261, Article 293; the maximum statutory sentence is the death penalty, for example, Article 236(3). It is impossible to infer the manifestations of "the circumstances are flagrant" in other crimes and the corresponding penalty for it from these present clauses, but we can deduce whether the condition of 5 year imprisonment serve as the condition of suspension of execution commuted to immediate execution is rationality or not from analyzing the penalty structure in the Penal Code. In the light of the present Penal Code, public surveillance and criminal detention are the lightest punishment, and life-imprisonment and death penalty are the most severe punishment in the whole penalty structure. As to the fixed-term imprisonment, two criminal scholars did research on its severity level in accordance with the Penal Code and pointed out that, "the fixed-term imprisonments of not more than 5 years is still the light punishment, but not less than 10 years, and so, the term between 5 years to 10 years is a medial level severe punishment [24]." The suggestion of ' 5 year fixed-term imprisonment' serving as one of conditions of suspension of execution of death penalty commuted to immediate execution is the medial severe punishment. In addition, this 5 year imprisonment in the suggestion is a declared sentence instead of statutory punishment. Thus the suggestion of "sentenced to not less than 5 year imprisonment" has substantially increased the condition and its rationality. It can't only enhance judicial operability instead of the vagueness of "the circumstances are flagrant", but as well, as for the normalization of sentencing, uniform sentence standards can prevent the sentencing conclusions varying according to the different interpretations of "the circumstances are flagrant" in different crimes.

\section{Further clearing the bound between suspension of execution and immediate execution of a death penalty}

Article 48 of the Penal Code provides that "if the immediate execution of a criminal punishable by death is not deemed necessary, a two-year suspension of execution may be pronounced simultaneously with the imposition of the death sentence [25]." Based on this provision, the applicable condition of the death penalty with suspension of execution ".....is not deemed necessary". For this, most of China's criminal scholars pointed out that, “.....is not deemed necessary' is so vague and lacking in clarity that it can't meet the substantial requirement of the principle of legality", so they asserted that this condition should be explicit [26]. First of all, the norm '...is not deemed necessary' is very vague and indefinite and lacks pertinent judicial interpretation, so it results in the application of the death penalty with suspension of execution lacking an objective and quantifiable standard and condition. And whether it'... is not deemed necessary' depends completely on the judge's subjective judgment. But this kind of judgment has an 
impact upon the defendant's life. Secondly, the lack of a uniform application standard will naturally lead to that judge sentencing differently, with varying results.

China's criminal scholars have proposed their own opinions in order to improve the applicable condition, '......is not deemed necessary' provided by Article 48, but these diverge greatly. These opinions normally fall into the following categories: 1) some scholars have asserted that "the judicial authorities should enact relevant guidance for the norm '.....is not deemed necessary"; 2 ) some scholars hold that the legislature should amend the Penal Code and enumerate certain circumstances of '..... is not deemed necessary' in the Penal Code, or the Supreme People's Court should make interpretation for it and enumerate as much detail of the circumstances as possible, so that there is a uniform application standard [6,27]." These are two approaches to improve the vague norm. 3) One important factor for determining applicable condition is the defendant's personal dangerousness. Some scholar think that, 'the defendant's personal dangerousness should serve as the only impacting element determining the norm of whether '.....is not deemed necessary' [22]. All of these are the main views on the improvement of this norm, and, to a great extent, they are reasonable and feasible. So the connection between suspension of execution and immediate execution of the death penalty should be made clear by enumerating possible circumstances according to personal dangerousness in the approach of the legislature or judicial interpretation.

\section{The strategy of reforming judiciary applicability of the death penalty Improving the basic applicable condition of the death penalty}

China's criminal scholars are always concerned and debating about the basic applicable condition of the death penalty, which is stipulated by Article 48 of 1997 Penal Code, which states that "the death penalty shall only be applied to criminals who have committed extremely serious crimes", which was amended from 1979 Penal Code which stated "who have committed the most heinous crimes [17,28]". According to the 1979 Penal Code, the extremely serious social harmfulness caused by the crime and the very high personal dangerousness exhibited by the criminal serve as the basic application conditions of death penalty. The terms of provision "committed extremely serious crimes" in 1997 Penal Code which should be taken into account from two aspects, namely, the nature and the circumstance of an offence are extremely serious, and the subjective culpability of the offender's mind is extremely serious [29]." The basic applicable conditions determine whether the death penalty is applied or not, and it can play a key role in controlling and limiting the application of the death penalty in judicial practice. But, in China, now, "the norms of 'extremely serious crimes' lack uniform and reasonable definition and interpretation, and so the function of limiting the use of death is limited in a certain extent [30]." Improving the basic applicable condition of death penalty is thus an important step in strictly controlling and limiting the death penalty.

In cases where the death penalty is still retained in the Penal Code in China, for the sake of further control and limiting of the application of the death penalty, China's legislature should amend and improve the basic applicable condition of the death penalty reference to international treaties signed and/or ratified by China's government. From the international perspective, "since the adoption of the International Covenant on Civil and Political Rights (Hereinafter: ICCPR) in 1966, human rights law has explicitly required restrictions on the use of the death penalty," and under this international standard, 98 states have already abolished death penalty de facto and de jure [31,32]. Even though the Chinese government has signed but not yet ratified the ICCPR, it should be abided by or consulted by the China's legislature. Article 6(2) of the ICCPR states that the "sentence of death may be imposed only for the most serious crimes in accordance with the law in force at the time of the commission of the crimes," thereby implying that the death penalty can only be imposed on the criminals who have committed a type of the most serious crimes, which "should not go beyond intentional crimes with lethal or other extremely grave consequences", pursuant to Economic and Social Council Resolution 1984/50 (Hereinafter: Resolution 1984/50) [33,23]. Here it particularly needs to be noted that, 'the most serious crimes' is totally different from '....extremely serious crimes' in the 1997 Penal Code, which should be explained by two elements, namely, that the nature and the circumstance of an offence are extremely serious, and the subjective culpability of the offender's mind is extremely serious", and the crime belonging to "extremely serious crimes "is the most serious in all types of crimes [34]. Thereby, the scope of the crimes punishable by death in the Penal Code is wider than that of Resolution 1984/50 which is limited to "not imposed for non-violent acts such as financial crimes, religious practice or expression of conscience and sexual relations between consenting adults nor as a mandatory sentence", in light of Human Rights Resolution 2005/59 [35]. By contrast, the scope of crimes punishable by death in the Penal Code includes such crimes as producing or selling fake medicines as the economic crime and other 24 non-violent crimes. In addition, considering the nature of crime categories, the crimes punishable by death are not all the most serious crimes, such as the crime of smuggling, trafficking in, transporting or manufacturing narcotic drugs and the crime of embezzlement and bribery. Therefore, China's death penalty reform should make reference to international treaties signed and ratified by China's government, abolishing the death penalty for the crime of embezzlement and bribery, the crime of rape and the crime of kidnapping; and strictly controlling and limiting the imposition of the death penalty on those crimes still punishable by death. So that death penalty can be effectively abolished de jure, and limited in a de facto sense.

\section{Reducing the scope of applicable objects of the death penalty}

Reducing the scope of applicable objects of the death penalty is another important approach in the de facto limiting of the use of the death penalty. Here, the condition of imposing the death penalty on elderly criminals and special subjects should be the main 
target for further reducing the death penalty's scope.

Increasing the imposing condition of death penalty on elderly criminals: ECOSOC resolution 1989/64, paragraph1(c) recommends that member states take steps towards establishing a maximum age beyond which a person may not be sentenced to death or executed", however, the 1997 Penal Code didn't establish the limitation of imposing death on elderly criminals until the Eighth Amendment in 2011, which "banned death penalty for criminals over the age of 75 at the time of trial; however, this shall not apply to cases of causing death to other persons by resorting to exceptionally cruel means [36,37]". It thereby implies that if imposing the death penalty on criminals over the age of 75, besides the basic condition that they committed an "extremely serious crime", there are two other basic necessary conditions that have to be met, namely, the criminal has not reached the age of 75 at the time of trial and didn't cause the death of another person by resorting to exceptionally cruel means. In contrast, the American Convention on Human Rights, Article 4 (5) prohibits the execution of those over 70 when the offence was committed; Article 49 (2) of the Criminal Code of the Republic of Kazakhstan prohibits the execution of anyone aged 65 by the time of the court has passed sentence $[38,39]$.

To a great extent, the Eighth Amendment has already significantly realized the humanization and mitigation of punishment more than ever before, and has limited the use of the death penalty. However, based on recent relevant research on the judicial practice, the limitation of the age of 75 looks, , to a certain extent, to be divorced from practice due to the fact that this kind of case, which meets both of the two conditions, scarcely takes place in judicial practice, and it thus lacks practical significance. Firstly, in accordance with the World Health Statistics 2015, the life expectancy at birth in China, for both sexes, was 75 years of age in 2013 [2]. The limitation of the age of 75 is thus beyond the longevity of most Chinese people. In addition, elderly people generally have greater physical and mental health problems, which will worsen when the person aged 75 is charged with a serious crime and enters the trial process. The outcome of this trial procedure will make the elderly perpetrator die shortly from the illness and lead the death sentence to be no longer necessary. Secondly, in judicial practice, the crime deliberately committed by elderly criminals over the age of 70 scarcely ever takes place; thereby, the limitation of 75 years of age is too high to be realistic. Therefore, the limitation should be decreased to 70 years of age when the offence was committed, similar to the limitation provided by the American Convention on Human Rights. Furthermore, some scholars hold that, "there should be no exception for elderly criminals exempted from death", namely, that the provision that "this shall not apply to cases of causing death to other persons by resorting to especially cruel means" should be deleted [2]. They consider that the present provision does not conform to the international practice of elderly criminals being exempted from the death penalty; and it isn't in accord with the actual practice that elderly people commit crimes [40]. For this reason, this paper agrees with the opinion that the conditions of imposing the death penalty on elderly criminals should decrease and the exception provision should be deleted, so as to further control and limit the use of the death penalty.

Limiting the imposition condition of the death penalty on special subjects: In accordance with the Penal Code, the special subjects for which the death penalty may be imposed include minor criminal or pregnant women or mental patients or elderly criminals (as has already been discussed). In addition, the special subjects relevant to criminal punishment should include mothers with dependent infants, intellectually disabled people, deaf-mutes or blind persons and so on, who should be given a lighter or mitigated punishment or be exempted from punishment due to suffering from physical or mental disease. However, these kinds of people cannot be exempted from imposing the death penalty in the light of the present Penal Code. So, the death penalty still plays a significant role in the structure of the criminal punishment system. I think that, such as mothers with dependent infants, intellectually disabled people and deaf-mutes or blind people as the criminal should be exempted from imposing the death penalty even though they have committed the most serious crimes. Because there are legal grounds for their being exempted from the death penalty, namely, Article 18 and 19 states that mental patients, deaf-mutes or blind people shall or may be given a lighter or mitigated punishment or be exempted from punishment, but mothers with dependent infants and intellectually disabled people are not explicitly stipulated by the relevant provisions of the present Penal Code [41]. In judicial practice, the judge could impose discretionary lighter punishment on them. Therefore, these kinds of people should be explicitly exempted from the death penalty.

\section{Conclusion}

The reform of the death penalty in China will be a long process. It commenced from the Eighth Amendment, which firstly abolished the death penalty for 13 crimes and improved other provisions relevant to the death penalty in the Penal Code, and was further promoted by the Ninth Amendment, which abolished the death penalty for 9 crimes and increased the applicable conditions of the death penalty with suspension of execution, so that the policy of "rarely applying the death penalty and executing the death penalty with caution" could further be implemented de jure and de facto [42]. The reform of the death penalty in the not too distant future in China should be committed by the approach of gradually abolishing the death penalty for non-violent and non-lethal crimes and finally for lethal violent crimes, and so finally completely abolishing the death penalty de jure and de facto. However, in cases where the death penalty hasn't yet been abolished completely, the applicable conditions of the death penalty with suspension of execution should be improved. In order to reform the death penalty, the reform of legislation is just one aspect; judicial control of the death penalty is another significant aspect, which needs to be focused upon by judicial authorities. Thus, the reform of the death penalty could be undertaken more effectively. 


\section{Acknowledgement}

I would like to thank the sponsor of China's Scholarship Council (CSC No. 201500500019, and the Stipendium Hungaricum Programme (Reference number: 2015-SH-14036).

\section{References}

1. Neumayer E (2008) Death Penalty: The Political Foundations of the Global Trend towards Abolition. Human Rights Rev 9: 241-68.

2. University of Oxford (1988) The Death Penalty in China-the road to reform, in the website of Faculty of Law.

3. Bingzhi Z (2015) New Thinking on Death Penalty in China: With the Perspective of Amendment IX (Draft) to Criminal Law. Ji Lin Univer J Soc Sci Ed 55: 5.

4. Li Shishi L (2014) The Explanations for the Draft of the Ninth Amendment to Criminal Law of People’s Republic Of China (Chinese).

5. Criminal Law of People Republic of China (2015) No.83, Article 151.

6. Zhou G (2015) Several Controversial Issues on the Draft of Amendment IX to the Criminal Law of the People's Republic of China. 5 Law Science Magazine 77-8.

7. The National People's Congress of People's Republic of China (2014) After the Fourth Plenary Session of the Communist Party Central Committee, the Legislator Focuses on the Power over someone's Life and Property: the Death Penalty for such, crimes of raising funds by means of fraud as 9 crimes is planning to be abolished.

8. The National People's Congress of People's Republic of China (2015) Zhang Dejiang Attending and Give a significant Speech in the 16th Session of 12th NPC Standing Committee.

9. Zhao B (2004) On Abolition of Death Penalty of Non-Violent Crimes in China, Symposia of 2004 Annual Conference of China Criminal LAW: Studying on Death Penalty, Press of People's Public Security University of China 779.

10. Qu S (2012) On the New Tendency of Death Penalty System and its Outlet in China: Reviewing the Death Penalty System in the Eighth Amendment 2:132-3.

11. Lu J (2012) On the Application of Terms of "Absolutely Determinate Death Penalty System".

12. Yun G, Fa Z (2010) No.1314.

13. Xi X, Yi C (2011) No.68.

14. Huo C (2005) Vengeance, Retributive Penalty and the Theory of Retribution: Explicating Culturally the Legal Concept of Chinese. Jilin People’s Publish House Ji Lin 5.

15. Wang Y (2012) On the Three Misunderstanding Areas of the Study of Death Penalty in China and the Adjustment of Approaches. Jilin Uni J Soc Sci Ed 52: 129-30.

16. Jing Z, Zhang Z (2004) The Chinese and foreign Origin of Death Penalty with Suspension of Execution and its Historical Development. 4, Legal Tradition in China and Western 71.

17. Criminal Law of People Republic of China (1997) Article 48.

18. Criminal Law of People Republic of China (1997) Article 51

19. The Ninth Amendment to Penal Code of People Republic of China (2015) Art 2.

20. Chen L (2014) On the 7 highlights of the Draft of Ninth Amendment to Penal Code of People Republic of China. Legal Daily News Oct 28: 3.

21. Here, the death row is distinctly different from the "death row" in America where the criminal spends a long time waiting for execution; even some inmates have to spend several decades awaiting execution. But here, death row is during the probation period, which is not less than two years. See David Von Drehle, 'The Death of the Death Penalty: why the Era of Capital Punishment is Ending, Time.

22. Zhang W, Huang W (2015) The Death Penalty with Suspension of Execution should serve as a Necessary Procedure of the Execution of Death Penalty. 23. Xia Y (2013) Rethinking the Applicable Conditions of the Death Penalty with Suspension of Execution: Taking the Case of Li Changkui as an Example. Studies in Law and Business 30: 46.

24. Lai Z, Jia J (2009) On the Severity Lever of Fixed-Term Imprisonment. Jiang Hai Acad J 4: 160-5.

25. Criminal Law of China (1997) Article 48.

26. Gao M, Xu H (2010) Three Dimensional Study on Our Death Sentence with Two-year Reprieve System. Political Sci Law 2: 2-9.

27. Gao J, Liu S (2005) Four-Dimensional Thoughts of the Conditions of Death Penalty with a Suspension of Execution. Contemporary Law Rev 91-7.

28. Criminal Law of People's Republic of China (1997) Article 43.

29. Gao M (2012) The Birth and Development of Criminal Law of the People's Republic of China Peking University Press, Beijing 225.

30. Zhang J (2014) Interpretation and Application to 'The Most Heinous Crimes': From the Perspective of Realistic Approach to Death Penalty Control. Hebei Law Sci 32: 65-73.

31. Salil S (2014) The Value of International Standards in the Campaign for Abolition of the Death Penalty. The Brown J World Affairs 21: 41-4.

32. Amnesty International (2014) Death Sentences and Executions in 2014, ACT 50/001/2015. 64.

33. International Covenant on Civil and Political Rights. No.14668, Article 6 (20).

34. Safeguards Guaranteeing Protection of the Rights of Those Facing the Death Penalty, Economic and Social Council Resolution 1984/50, Article 1.

35. The Question of the Death Penalty, Human Rights Resolution 2005/59, Article 7( f).

36. The Economic and Social Council Resolution 1989/64, Implementation of the Safeguards Guaranteeing Protection of the Rights of Those Facing the Death Penalty, Paragraph1(c).

37. The Eighth Amendment to Criminal Law of People Republic of China (2011) Article 3.

38. The American Convention on Human Rights, Article4 (5).

39. The Criminal Code of the Republic of Kazakhstan (1997) Article 49(2).

40. World Health Organization (2015) World Health Statistics 2015. Geneva. 
41. Criminal Law of People Republic of China (1997) Article 18-9.

42. Zhao B (2014) Reform in Death Penalty System. China Renmin University Press, Beijing 78. 